\title{
Antibiotic susceptibility Patterns against Upper Respiratory Tract Pathogens in Tertiary Care Hospitals of Lahore, Pakistan
}

Kalim Ullah

University of Balochistan

Marvi Baloch

University of Balochistan

Javeid lqbal

University of Balochistan

Ayaz Ali Khan

University of Balochistan

Hamid Saeed ( $\nabla$ hamid.pharmacy@pu.edu.pk)

University of the Punjab https://orcid.org/0000-0002-1400-4825

Muhammad Islam

University of the Punjab

Research article

Keywords: URTIs, Antibiotics, Ceftazidime, Cefuroxime, Amikacin, Imepenem, Lahore, Pakistan, Resistance, Sensitivity, Antibiogram

Posted Date: April 22nd, 2020

DOI: https://doi.org/10.21203/rs.2.19297/v2

License: (c) (i) This work is licensed under a Creative Commons Attribution 4.0 International License.

Read Full License 
The authors have withdrawn this preprint from Research Square 